Open Access to Pharmaceutical and Medical Research

(C) 2011-18, publisher and licensee JDDT, This is an Open Access article which permits unrestricted non-commercial use, provided the original work is properly cited

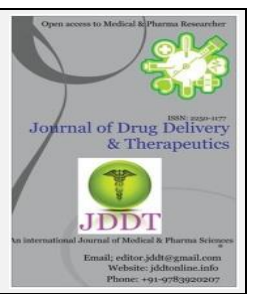

Open $\mathcal{O}_{\text {Access }}$

Research Article

\title{
Desmostachya Bipinnata - A Novel Farming Method
}

\author{
Dr. Nagarajnaik Chavhan ${ }^{*}$, Dr. Shashirekha H.K ${ }^{2}$, Dr. Bargale Sushant Sukumar ${ }^{3}$, Dr. Prakash. L. Hegde ${ }^{4}$ \\ 1. PG Scholar ${ }^{*}$, Department of Samhita and Siddhanta, SDM college of Ayurveda and Hospital, Hassan. \\ 2. Associate professor ${ }^{2}$, Department of Samhita and Siddhanta, SDM college of Ayurveda and Hospital, Hassan.
}

3. Assistant Professor ${ }^{3}$, Department of Swasthavritta and Yoga, Sri Dharmasthala Manjunatheshwara College of Ayurveda and Hospital Hassan, Karnataka.

4. Professor ${ }^{4}$ Department of Dravya Guna Sri Dharmasthala Manjunatheshwara College of Ayurveda and Hospital Hassan, Karnataka.

\begin{abstract}
Grasses are the most flourishing plants on earth as monocotyledonous plants. They have been a survivor on the planet despite of various ecological changes. They deserve the medicinal value and therefore considered as novel repositories. The grass family is considered as sacred, it has great significance in Ayurveda because of medicinal as well as clinical properties. Methods: Kusha grows commonly and abundantly at agricultural field especially in dry and sandy soil. As are more grass species found in the moderately temperate and moist region of India whereas Kusha can be grown indoors and outdoors. Results: Growth of plants has seen within duration of 20 to 25 days. In this study effort made to explain the natural cultivation methods for getting best medicinal effect in drug Kusha. Efficacy of the naturally grown plant shown the good result in laboratory investigations as compare to the manual grown. Usage of single drug is cost effective in day today practice by adopting natural farming method. Conclusion: By following proper plantation methods one can yield high medicinal properties in the drugs to reach the expected result.
\end{abstract}

Keywords: Cultivation methods, Kusha, Mutravaha Srotas, Trinapanchamula.

Article Info: Received 24 June 2019; Review Completed 11 Aug 2019; $\quad$ Accepted 20 Aug 2019; Available online 30 Aug 2019

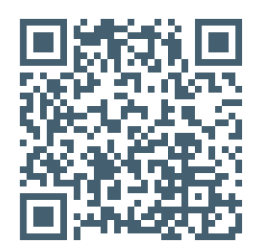

Cite this article as:

Chavhan N, Shashirekha HK, Bargale SS, Hegde PL, Desmostachya Bipinnata - A Novel Farming Method, Journal of Drug Delivery and Therapeutics. 2019; 9(4-A):471-476 http://dx.doi.org/10.22270/jddt.v9i4-A.3496

*Address for Correspondence:

Dr. Nagarajnaik Chavhan, PG Scholar Department of Samhita and Siddhanta, SDM College of Ayurveda and Hospital Hassan, Karnataka-573201

\section{Introduction}

Desmostachya bipinnata is the Latin name for Kusha which is frequently mentioned for the multi therapeutic purpose in Ayurveda classics. Kusha is one among the Trina Panchamula well identified in the form of grass and beneficial in Pitta Vata Paradhana Disease ${ }^{1}$. Basically they have Mutrala property and best remedy for the Mutravaha Srotogata Vikara ${ }^{2}$. As Trina Panchamula (Mainly 5 drugs) are having similar Rasa Guna Virya Vipaka and posses with Tridoshahara property ${ }^{3}$. The Kusha grass or Dharbai is considered very sacred by all Hindus and is used in certain religious ceremonies, especially those performed in connection with ancestors 4 . It is very essential to know the cultivation of the Kusha grass for the purpose of better efficacy. The efficacy of drug is evaluated by adopting and cultivating through a new organic farming method. Kusha grows commonly and abundantly in fallow agricultural fields, along with the roadsides on boundaries and bunds of agricultural fields on dry and sandy soils, it often forms dense tufts producing a dominating patch of plants. It is one of the hardiest and most aggressive weeds in agricultural fields growing either with the crop or on field margins. It is very difficult to manage or eradicate established populations because of the extensive and deep rhizomatous root system. As are more grass species found in the moderately temperate and moist region of India. Flowering and fruiting occurs from May to July, maturing from August to October. On moderately alkaline calcareous soils, the monsoon rains trigger active growth of Kusha in June and plant biomass attains a peak during the rainy season in September. The leaves senesce with the onset of dry weather during winter months from November to February followed by a spurt of growth in summer months due to regeneration of shoots from the perennial rhizomes. Being a deep-rooted grass, 52$55 \%$ of the root biomass remains concentrated in the top 10 $\mathrm{cm}$ of the soil, whereas the rhizomes and roots penetrate deeper than $1.5 \mathrm{~m}^{5}$. With proper manuring and organic methods one can yield the better efficacy in cultivated grasses. 
The farming (Agro- technique) method was adopted by following different steps

Individual species are often tolerant of a wide range of climatic and cultural conditions, and the great diversity of grasses means there are species and cultivated varieties suited for almost any purpose and place. Properly selected and used, grasses and their relatives can contribute more beauty and sustained interest with less maintenance than almost any other group of herbaceous landscape plants. This topic offers general concepts, techniques, and recommendations for cultivating and maintaining the growing grasses ${ }^{6}$. Adaptation of Self cultivation and preparation of the drugs are safe to use because of personal concern. To get good potency and efficacy a new cultivation methods has been followed.

1. Environmental requirements for cultivation of Kusha

2. Soil selection

3. Land preparation

4. Plantation Method

5. Manuring

6. Irrigation and drainage

7. Water Supply

8. Harvesting

\section{Environmental requirements for cultivation of Kusha}

Cultivation of Kusha is widely distributed in arid and semi arid regions of India having an annual rain fall off 250$750 \mathrm{~mm}$. In Hassan city generally growth is more supportive because it is having average rainfall of $1041 \mathrm{~mm}$, air temperature is $23.3^{\circ} \mathrm{C}$, soil temperature regime is isohyperthermic in nature. It is however very drought tolerant and known to survive where annual rainfall may be as low as $54 \mathrm{~mm}$, and will also be found in higher rainfall zones, above $1000 \mathrm{~mm}^{7}$.

\section{Soil selection}

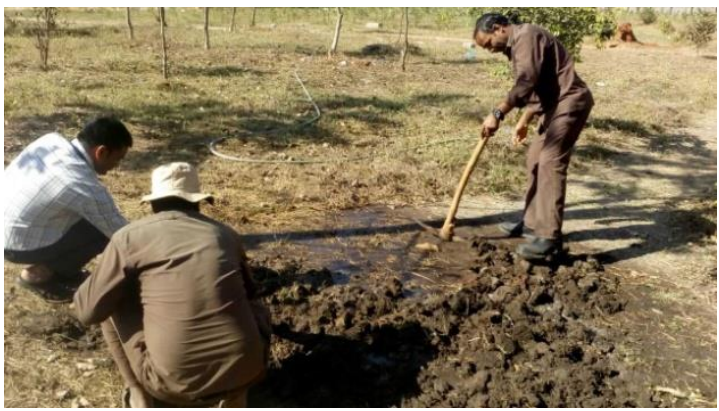

Figure-1 Soil selection

$10 X 5$ meters of land has been selected in the SDM college of Ayurveda campus. Sacrificial grass grows on verity of soil, light loams and sandy soil are preferred to heavy soils. In Hassan city sandy loam to clay is present it has great tolerance to salinity and sodicity. The soil has to be wet at the root zone but should not be stagnated. The grass does not thrive well on water lodged and flood prone lands. Phenomenal yield are obtained from very deep fertile soil rich in organic matter and nutrient elements. It tolerates a PH range from 5-8 (Figure-1).

\section{Land preparation}

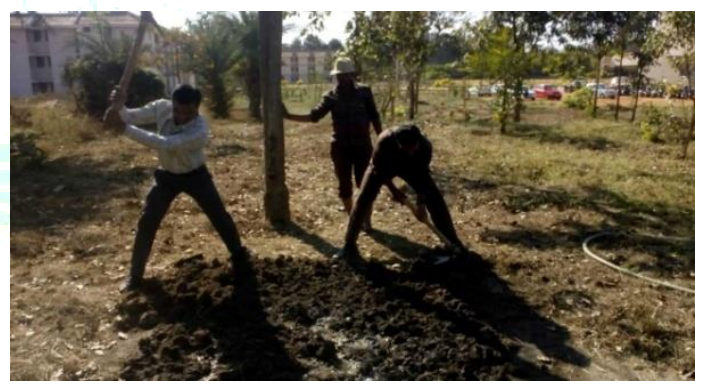

Figure 2- Land Preparation

Initially it was cleaned with the bushes, removal of thorns, weeds etc. are done. Pits of 1-2 meters deep are made with a gap of 2-3 meters in between for the proper growth (Figure 2)

\section{Plantation Method}

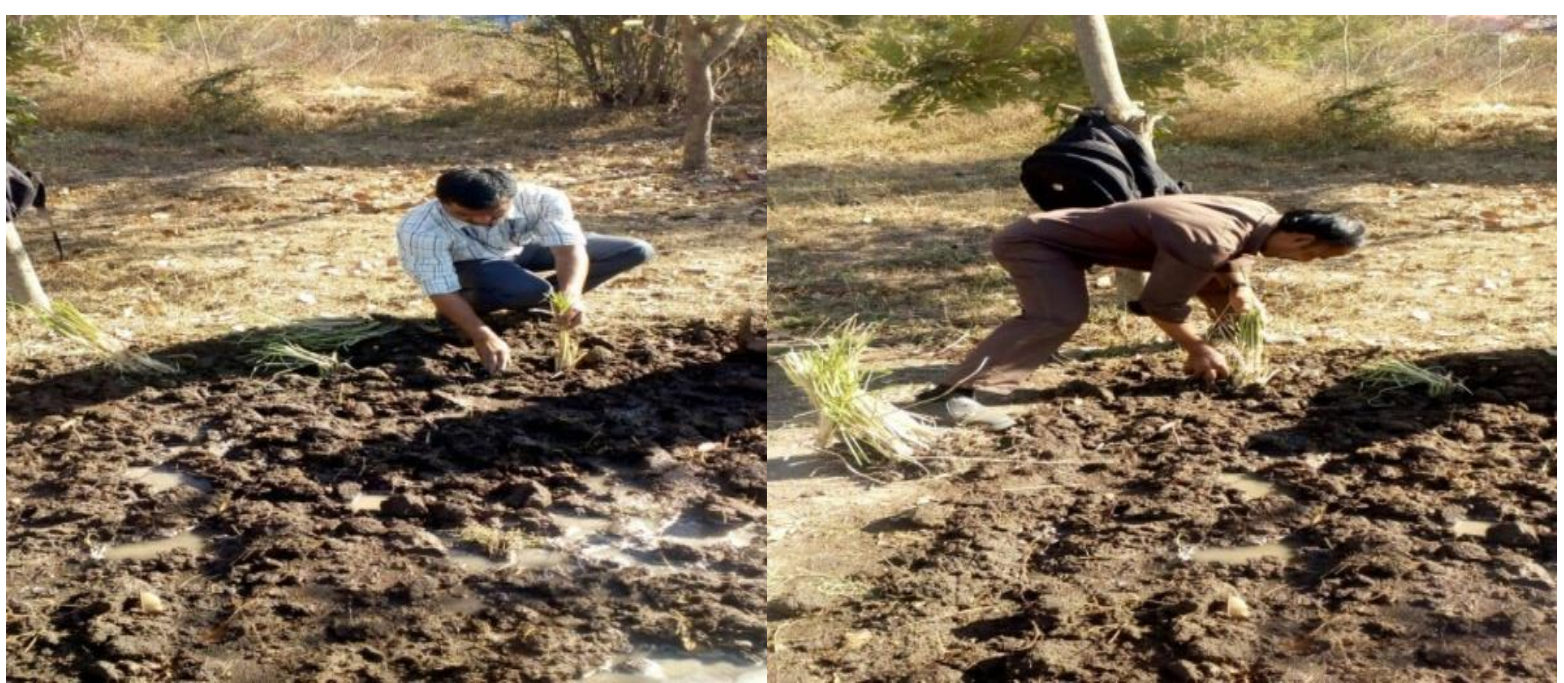

Figure-3 Plantation Method 
A new plantation method has been followed in this study that is with a bunch of rooted slips has been brought from agricultural land and planted in a selected area. Planting is done by rooted slips measuring approximately 2-3 meters of moderately matured stems along with roots. Planted in vertical position by making a pit of 1-2 meters deep, and soil around the stem has to be pressed tightly for better root growth. Surrounding to the selected land a wall has been prepared to supply and stoppage of water.

\section{Manuring}

Manuring is done for every 15-20 days, in that mainly cow dung is used. Cow dung is having medicinal property and it can be used in the treatment of many deseases. It improves the soil structure (Aggregation) so that the soil holds more nutrients and water therefore becomes more fertile. Along with that it encourages the soil microbial activity which promotes the soils trace mineral supply, improving plant nutrition. It also contains some nitrogen and other nutrients that assist the growth of the grass 9 .

\section{Irrigation and drainage}

The field is provided with good drainage during the rainy season as the crop cannot stand water stagnation. The first irrigation is done at the time of the planting and the life irrigation on the third day after planting. A frequency of subsequent irrigations depends upon the rainfall and weather conditions. During summer is 3-4 days depending on the soil quality as per standard irrigation interval.

\section{Water Supply}

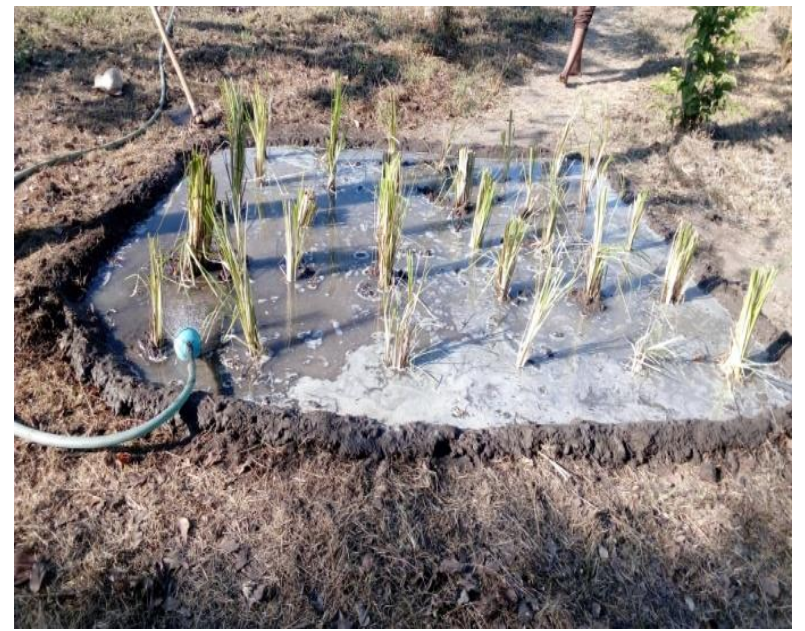

Figure-4 Water Supply

In this field water is supplied for every alternate day in the summer season and in rainy season as per the need. In both the season water supplied in the morning time because it keeps the grass cooler during the hot parts of the day, which means less stress on the grass. Water long enough to moisten the soil about 6 inches down, which is the depth of a healthy grass root system. It takes about one inch of water to wet normal to that depth (Figure-4).

\section{Harvesting}

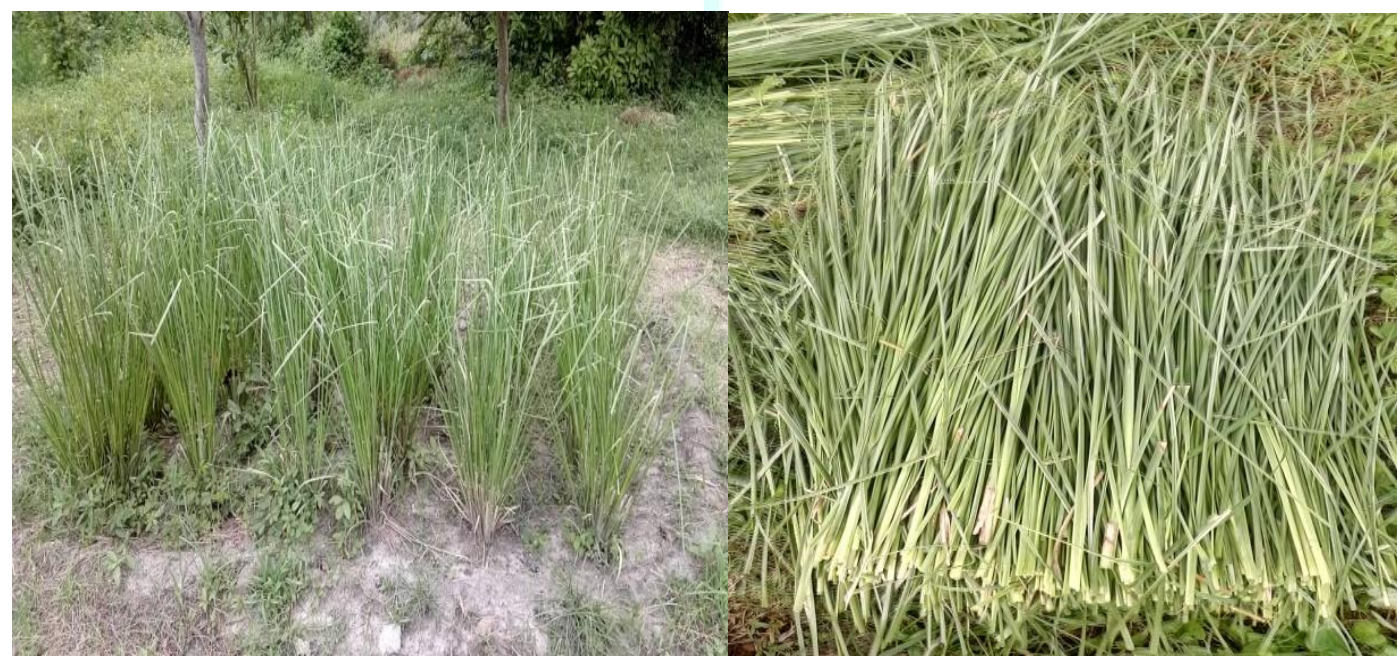

Figure-5 Harvesting of Kusha for Juice extract

Mainly this grass is used for the purpose of medicine in the form of juice so grass was collected on $15^{\text {th }}$ day. One more study on wheat grass it says that wheat grass grows to about 5 inches and within about 10 days it reaches 6-7 inches this is the best time to get the proper and good quality of juice so this can also be considered as the selected time for harvesting ${ }^{10}$ (Figure-5).
Drug Authentification and Drug Analysis- Drug authentification that ensures the correct plant species, here in this test the part of plant used is raw materials for drug Authentification and drug is identified as Desmostachya bipinnata (Kusha). 
1. Drug Authentification

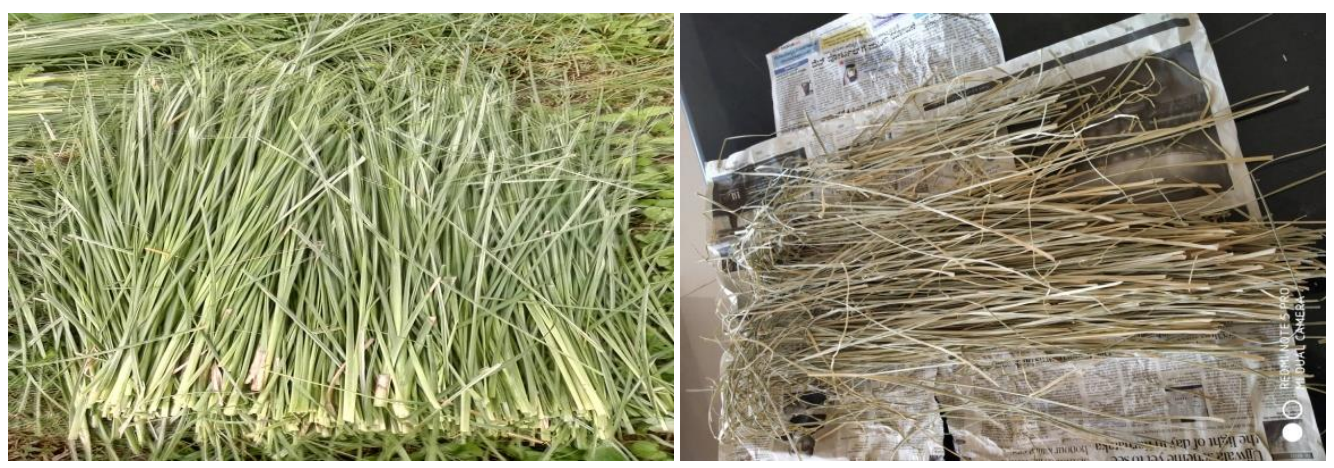

Figure-6 Kusha Grass for drug Authentification

Drug Authentification (Certificate no SDMCAH-DG/2018/16 Dated on 01/09/2018) and Drug analysis (Certificate no SDMCAH-DG/E/2018/03 Dated on 26/12/2018) was done in Department of Dravyaguna at Sri Dharmasthala Manjunatheshwara college of Ayurveda and Hospital Hassan Karnataka and following investigations were performed and results are obtained.

2. Drug Analysis- Drug analysis was done in following different levels, they are as follows

A. Preliminary Phytochemical evaluation was done as per the standard methods

B. Physical Analysis and evaluation

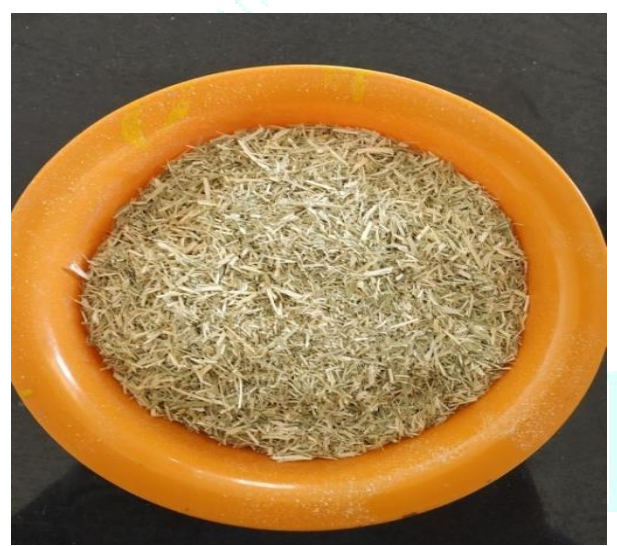

Figure-7 Coarse powder of Kusha for Drug analysis

A. Preliminary Phytochemical evaluation was done as per the standard methods

1. Test for Carbohydrates-

2. Test for Proteins

3. Test for Alkaloids

4. Test for Saponin Glycoside

5. Test for Tannins

Preliminary Phytochemical evaluation and results were compared with the standards, the results shown the presence of Alkaloids and Carbohydrates.

Table 1: Preliminary Phytochemical values

\begin{tabular}{|c|c|c|}
\hline S.N & Test for & Sample \\
\hline 1. & Alkaloid & +ve \\
\hline 2. & Carbohydrates & +ve \\
\hline 3. & Tannin & -ve \\
\hline 4. & Saponin & -ve \\
\hline 5. & Protein & -ve \\
\hline
\end{tabular}

1. Test for Carbohydrates:

a) Fehling's test Mix $1 \mathrm{ml}$ Fehling's A and $1 \mathrm{ml}$ Fehling's B solutions boil for oneminute. Add equal volume of test solution. Heat in boiling water bath for 5-10 min.First yellow, then brink red ppt. is observed.

b) Benedict's test Mix equal volume of Benedict's reagent and test solution in Test tube. Heat in boiling water bath for $5 \mathrm{~min}$. Solution appears green, yellow or reddepending on the amount of reducing sugar present in test solution.

2. Test for Proteins

a) Xanthoprotein test: Mix $3 \mathrm{ml}$ test solution with $1 \mathrm{ml}$ conc. Sulphuric acid. White ppt.is formed. Boil it. Precipitate turns yellow. Add Ammonium hydroxide ppt. turnsorange.

b) Precipitation test: The test solution gives white colloidal ppt. with $5 \%$ lead acetate.

3. Test for Alkaloids

a) Dragendorff's test: To $2 \mathrm{ml}$ of the test solution, add few drops of Dragendorff's Reagent. Orange brown ppt. is formed.

b) Wagner's test: To $2 \mathrm{ml}$ of the test solution, add few drops of Wagner's reagent.Reddish brown ppt. is formed.

4. Test for Saponin Glycoside

a) Foam test: Shake the test solution vigorously with water. Persistent foam isobserved.

5. Test for Tannins

a) Ferric chloride test: To $2 \mathrm{ml}$ of the test solution, add few drops of 5\% Ferric chlorideSolution, deep blueblack colour is formed.

b) Lead acetate test: To $2 \mathrm{ml}$ of the test solution, add few drops Lead acetate solution, white ppt. is formed.

\section{B. Physical Analysis}

1. Loss on drying at $105^{\circ \mathrm{C}}$

2. Total Ash

3. Acid insoluble

4. Ash Alcohol soluble extractive

5. Water soluble extractive 
Table no 2: Physico chemical values

\begin{tabular}{|c|c|c|c|}
\hline Sl .No & Test Done & Obtained Value & Standard value11 \\
\hline 01. & Loss on Drying & $4.89 \%$ & - \\
\hline 02. & Total Ash & $9.5 \%$ & Not more than $9 \%$ \\
\hline 03. & Acid Insoluble Ash & $5 \%$ & Not more than $7 \%$ \\
\hline 04. & Alcohol Soluble Extractive & $0.25 \%$ & Not less than $3 \%$ \\
\hline 05. & Water Soluble Extractive & $1.75 \%$ & Not less than $5 \%$ \\
\hline
\end{tabular}

1. Loss on drying at $105^{\circ} \mathrm{C}-10 \mathrm{~g}$ of sample was placed in tarred evaporating dish. It was dried at $105^{\circ} \mathrm{C}$ for 5 hours in hot air oven and weighed. The drying was continued until difference between two successive weights was not more than 0.01 after cooling in desiccators. Percentage of moisture was calculated with reference to weight of the sample.

2. Total Ash - 2g of sample was incinerated in a tarred platinum crucible at temperature not exceeding $450^{\circ} \mathrm{C}$ untilcarbon free ash is obtained. Percentage of ash was calculated with reference to weight of the sample.

3. Acid insoluble Ash - To the crucible containing total ash, add $25 \mathrm{ml}$ of dilute $\mathrm{HCl}$ and boil. Collect the insoluble matter on ashless filter paper (Whatmann 41) and wash with hot water until the filtrate is neutral. Transfer the filterpaper containing the insoluble matter to the original crucible, dry on a hot plate and ignite to constantweight. Allow the residue to cool in suitable desiccators for 30 mines and weigh without delay. Calculatethe content of acid insoluble ash with reference to the air-dried drug.

4. Alcohol soluble extractive - Weigh accurately $4 \mathrm{~g}$ of the sample in a glass stoppered flask. Add $100 \mathrm{ml}$ of distilled Alcohol (approximately 95\%). Shake occasionally for 6 hours. Allow to stand for 18 hours. Filter rapidly takingcare not to lose any solvent. Pipette out $25 \mathrm{ml}$ of the filtrate in a pre-weighed $100 \mathrm{ml}$ beaker. Evaporateto dryness on a water bath. Keep it in an air oven at $105 \mathrm{C}$ for 6 hours, cool in desiccators for 30 minutesand weigh. Calculate the percentage of Alcohol extractable matter of the sample. Repeat theexperiment twice, and take the average value.

5. Water soluble extractive - Weigh accurately $4 \mathrm{~g}$ of the sample in a glass stoppered flask. Add $100 \mathrm{ml}$ of distilled water, shake occasionally for 6 hours. Allow to stand for 18 hours. Filter rapidly taking care not to lose any solvent.Pipette out $25 \mathrm{ml}$ of the filtrate in a preweighed $100 \mathrm{ml}$ beaker. Evaporate to dryness on a water bath. Keep it in an air oven at $105 \mathrm{C}$ for 6 hours. Cool in a desiccator and weigh. Repeat the experiment twice. Take the average value.

\section{Discussion}

Organic Agriculture systems are not a repudiation of the assets of modern Agriculture technology, neither are they defined by the simple elimination of synthetic fertilizers or pesticides. It converses soil fertility and soil erosion through implementation of appropriate conservation principles. Cultivation of new drug is a source of economic and physical security for poor, marginalized and vulnerable communities in present scenario.To provide a foodstuff of high nutritional quality in sufficient quantity and give it to all livestock the conditions of life that confirm to their physiological needs.
Organic farming describes two major aspects of alternative agriculture they are substitution of manures, other organic fertilizers and the use of biological pest control instead of chemical pest control.

Site selection influence the growth and yield of grass it includes temperature, water or rain fall, light, relative humidity and wind. Soil must have the specific characters like soil type, depth, drainage, texture, organic matter content, $\mathrm{PH}$, and fertility with respect to macronutrient and micronutrient. Land preparation begins after your last harvest or during follow period with cleaning, ploughing to overturn the soil harrowing to break the soil clods levelling the field. Planting that only requires the use of pre grown plants or seedlings or vegitatively propagated clones for field planting. Manures improve the fertility of the soil by adding lots of nutrients, such as nitrogen that is trapped by bacteria in the soil. Irrigation and drainage are artificial application of water to land and artificial removal of excess water from the land as per the climatically change water is supplied in present study. Harvesting grass at any point usually about 4-6 inches tall for juicing but in present study on $20^{\text {th }}$ day grass is collected for the juicing purpose.

Drug analysis includes the aspects of identifying novel drugs assessing their affinity and specificity, characterising their molecular structures and testing their efficacy and comparing with standard one. In present drug study the Preliminary Phytochemical evaluation results show the presence of Alkaloids and Carbohydrates in the sample and in Physico chemical evaluation obtained values are in Loss on Drying-4.89\%, Total Ash-9.5\%, Acid Insoluble Ash-5\%, Alcohol Soluble Extractive-0.25\%, and Water Soluble Extractive-1.75\%.

\section{Conclusion}

- Organic agriculture is the key to a sound development and a sustainable environment for the development of drugs.

- Basic cultivation methods are plays an important role in getting good potent drugs.

- To avoid the side effects of pesticide is also one of the needs for organic farming approach.

- $\quad$ Natural method of pit planting has shown more Kusha yield.

- Standardization of the drugs will also achieve by the natural farming method. 


\section{References}

1. Vaidhya jadavaji Trikamjiacharya, SushrutaSamhitha; of Dalhanacharya, Sutrasthana; Dravya sangrahaniyam adhyaya: Chapter 38, Shloka 75. Varanasi; Chowkamba Sanskrit Samstana, 2017; p 169.

2. Vaidhya jadavaji Trikamjiacharya, SushrutaSamhitha; of Dalhanacharya, Sutrasthana; Dravya sangrahaniyam adhyaya: Chapter 38, Shloka 75-76. Varanasi; Chowkamba Sanskrit Samstana, 2017; p 169.

3. Dr.Prakash L Hegde and Dr.Harini.A, Dravyaguna vijnana; Volume III: Chapter 76; New delhi; Chaukhambha Publications, 2016;p no 420-421.

4. https://en.m.wikipedia.org
5. https://www.cabi.org/isc/datasheet/18479

6. https://what-when-how.com/grasses/cultivationmaintenance-grass/

7. https://en.m.wikipedia.org

8. http://www.maralika.com/GRASS.html

9. https://en.wikipedia.org/wiki/Manure

10. https://www.thedailygardener.com/wheatgrass

11. Department of health, The Ayurvedic Pharmacopeia of India $1^{\text {ST }}$ edition, New Delhi, Govt of India, Dept. of Ayush 2006, Part - 1, Volume -3,pg. no.104-105 